\title{
IR, Raman and SERS Spectra of 2-(Methoxycarbonylmethylsulfanyl)-3,5-dinitrobenzene Carboxylic Acid
}

\author{
Asha Raj, ${ }^{a}$ K.Raju, ${ }^{b}$ Hema Tresa Varghese,${ }^{c}$ Carlos M. Granadeiro, ${ }^{d}$ Helena I. S. Nogueira ${ }^{d}$ \\ and C. Yohannan Panicker*,e
}

${ }^{a}$ Department of Physics, Government Polytechnic College, Attingal, Kerala, India

${ }^{b}$ Department of Physics, University College, Trivandrum, Kerala, India

${ }^{c}$ Department of Physics, Fatima Mata National College, Kollam, Kerala, India

${ }^{d}$ Department of Chemistry, CICECO, University of Aveiro, 3810-193 Aveiro, Portugal

${ }^{e}$ Department of Physics, TKM College of Arts and Science, Kollam, Kerala, India

\begin{abstract}
O ácido carboxílico 2-(metoxicarbonilmetilsulfanil)-3,5-dinitrobenzeno foi preparado por substituição nucleofílica. Seus espectros de infravermelho e Raman com transformada de Fourier foram obtidos e analisados. O espalhamento Raman intensificado pela superfície (SERS) foi obtido sobre prata coloidal. Os números de onda vibracionais foram computados pela teoria do funcional de densidade (DFT) com a base híbrida B3LYP/6-31G* e foram comparados com valores experimentais com boa concordância. Interações metal-molécula significativas foram substanciadas por um sinal Ag-O intenso nos espectros SERS, indicando a proximidade dos grupos nitro e carbonila à superfície de prata. Estudos SERS sugerem uma orientação inclinada da molécula sobre a superfície metálica.
\end{abstract}

2-(Methoxycarbonylmethylsulfanyl)-3,5-dinitrobenzenecarboxylic acid was prepared by nucleophilic substitution. FT-IR and FT-Raman spectra of 2-(methoxycarbonylmethylsulfanyl)-3,5dinitrobenzenecarboxylic acid were recorded and analyzed. Surface enhanced Raman scattering (SERS) spectrum was recorded on a silver colloid. The vibrational wavenumbers were computed by density functional theoretical (DFT) computations at the B3LYP/6-31G* level and they were found to be in good agreement with the experimental values. Significant metal-molecule interaction has been substantiated by the appearance of intense Ag-O mode in the SERS spectrum and this is indicative of the nearness of nitro and carbonyl group to the silver surface. SERS studies suggest a tilted orientation of the molecule at the metal surface.

Keywords: nitro, FT-IR, FT-Raman, SERS, DFT, methoxy carbonyl

\section{Introduction}

The main characteristic of the surface enhanced Raman scattering (SERS) is the enormous enhancement of the Raman signal of a molecule when the spectrum is recorded in the neighbourhood of a metallic rough surface. ${ }^{1,2}$ The nucleophilic substitution of $o$-nitrochlorobenzenes with substituted methanethiolates, catalyzed with triethylamine or pyridine, has been used to prepare a series of appropriately substituted methyl-o-nitrophenylsulfides. ${ }^{3}$ Sulfenyl carbonyl compounds are an interesting family of molecules

*e-mail: cyphyp@ rediffmail.com related to important biological systems and the anomeric and mesomeric effects in methoxycarbonylsulfenyl chloride is reported by Erben et al. ${ }^{4}$ Vallejos et al. ${ }^{5}$ reported the experimental investigation of the structure and vibrational properties of methoxycarbonylsulfenyl isocyanate. Nitro derivatives of salicylic acids as a donor in solid state coordination compounds have been studied by Lajumen et al. ${ }^{6}$ and the study of metal complexes with 3,5-dinitrosalicylic acid is also reported. ${ }^{7,8}$ Structural confirmation of the 3,5-dinitrosalicylate anion coordination ability to metal ions have been reported by Valigura et al. ${ }^{9,10}$ and they have reported the characterization of complex by elemental micro analysis, electronic, IR and 
EPR spectra. 3,5-Dinitrosalicylic acid is an example of a proton donor having both carboxyl and hydroxyl groups, and provides one of the best chemical synthons for the construction of hydrogen-bonded structural motifs. ${ }^{11}$ The acid has provided examples of polymorphism in which associations with solvent molecules such as water, dioxane and tert-butyl alcohol give a variety of hydrogen-bonded molecular assemblies. ${ }^{12,13}$ Panicker et al. ${ }^{14}$ reported the IR, Raman and SERS spectra of methyl(2-methyl-4,6-dinitrophenylsulfanyl)ethanoate. $A b$ initio quantum mechanical method is at present widely used for simulating IR spectrum. Such simulations are indispensable tools to perform normal coordinate analysis so that modern vibrational spectroscopy is unimaginable without involving them. So far, there is no report of the vibrational spectral analysis of the title compound. In the present study, the IR, Raman and surface enhanced Raman scattering spectra of 2-(methoxycarbonyl methylsulfanyl)3,5-dinitrobenzenecarboxylic acid were investigated to get an idea regarding the orientation of the molecule on the silver surface. Theoretical calculations of the vibrational wavenumbers were made using Gaussian03 software package on a personal computer. ${ }^{15}$

\section{Experimental}

The title compound was prepared by the protocol given by Dudova et al. ${ }^{3}$ Methyl sulfanylethanoate $(4.46 \mathrm{~g}, 0.042 \mathrm{~mol}$ ) was added drop wise to a stirred solution of 2-chloro-3,5dinitrobenzoic acid $(9.86 \mathrm{~g}, 0.04 \mathrm{~mol})$ in 1,2-dimethoxy ethane $(25 \mathrm{~mL})$ to a $100 \mathrm{~mL}$ flask at room temperature under an inert atmosphere of Ar. Triethylamine (4.05 g, $0.04 \mathrm{~mol}$ ) was added at once to neutralize the carboxy group. More triethylamine $(4.05 \mathrm{~g}, 0.04 \mathrm{~mol})$ was then added drop wise with stirring over a period of $c a .30 \mathrm{~min}$. The mixture was stirred for an additional $10 \mathrm{~min}$ and then poured into dilute aqueous hydrochloric acid $(1: 1,30 \mathrm{~mL})$. The product was extracted with chloroform $(3 \times 50 \mathrm{~mL})$, the organic phase was dried over $\mathrm{Na}_{2} \mathrm{SO}_{4}$ and the solvent was removed under reduced pressure. The residue was recrystallized from chloroform yielding $7.8 \mathrm{~g}(62 \%)$ of the product, $\mathrm{mp} 109-111^{\circ} \mathrm{C}$. The elemental analysis is: solvent for crystallization, chloroform; calculated/found (\%) C 37.98/37.99, H 2.55/2.56, N 8.86/9.13, S 10.14/10.16. Chemical shifts $(\delta)$ : solvent, DMSO- $d_{6}: \mathrm{H}_{7} 8.69, \mathrm{H}_{10}$ $8.94(\mathrm{~d}, J 2.5 \mathrm{~Hz}), \mathrm{CH}_{2} 3.92 \mathrm{~s}, \mathrm{OCH}_{3} 3.60 \mathrm{~s},{ }^{13} \mathrm{C} \mathrm{NMR}$ $(\delta)$ : solvent DMSO- $d_{6}$; Ar-S-; $155.42\left(\mathrm{C}_{4}\right), 147.91\left(\mathrm{C}_{6}\right)$ $141.48\left(\mathrm{C}_{3}\right), 134.26\left(\mathrm{C}_{1}\right), 127.35\left(\mathrm{C}_{5}\right), 121.61\left(\mathrm{C}_{5}\right), \mathrm{COOH}$ group: (169.27) (CO), $38.6 \mathrm{CH}_{2}, 166.1, \mathrm{CO}$ of $\mathrm{COOCH}_{3}$, $53.44 \mathrm{CH}_{3}$. The ${ }^{1} \mathrm{H}$ and ${ }^{13} \mathrm{C}$ NMR spectra were measured at $25^{\circ} \mathrm{C}$ with an AMX 360 Bruker spectrometer at the wavenumber of 360.14 and $90.57 \mathrm{MHz}$, respectively. For the measurements the substances were dissolved in $\mathrm{CDCl}_{3}$ or $\left(\mathrm{CD}_{3}\right)_{2} \mathrm{SO}\left(5 \%\right.$ solutions). The $\delta{ }^{1} \mathrm{H}$ chemical shifts are referred to the signal of $\mathrm{HMDSO}$ in $\mathrm{CDCl}_{3}$ solutions $\left(\delta^{1} \mathrm{H}\right.$ : $0.05)$ and to the solvent signal in $\left(\mathrm{CD}_{3}\right)_{2}$ SO solutions $\left(\delta^{1} \mathrm{H}\right.$ : 2.55). The $\delta{ }^{13} \mathrm{C}$ chemical shifts are referred to the signals of the two solvents $\left(\delta{ }^{13} \mathrm{C}: 77.0\right.$ and 39.6 , respectively). The analysis of the proton spectra was carried out according to the rules for the first-order splitting with the help of the integral intensities. The ${ }^{13} \mathrm{C}$ NMR spectra were measured with full decoupling from the protons, and the signals were assigned with the help of SCS. The quaternary carbon atoms and $\mathrm{CH}$ groups were differentiated by means of the APT pulse sequence. The elemental analyses were carried out on an automatic analyser EA 1108 (Fisons). The FT-IR spectrum (Figure 1) was recorded using a Perkin-Elmer spectrum one FT-IR spectrometer in the region 450-4000 $\mathrm{cm}^{-1}$ with the sample in standard $\mathrm{KBr}$ pellet technique. The spectral resolution was $2 \mathrm{~cm}^{-1}$. Raman spectra (Figures 2 and 3) were recorded on a Bruker RFS 100/s FT instrument (Nd:YAG laser, $1064 \mathrm{~nm}$ excitation). The aqueous silver colloid used in the SERS experiments was prepared by reduction of silver nitrate by sodium citrate, using the LeeMeisel method. ${ }^{16}$ SERS of the title compound was obtained as previously described, ${ }^{17}$ summarized next. Solution of the compound were made up in ethanol $\left(0.1 \mathrm{mmol}\right.$ in $1 \mathrm{~cm}^{3}$ of solvent) and transferred by a micro syringe into the silver colloid ( $10 \mu \mathrm{L}$ in $1 \mathrm{~mL}$ of the colloid) such that the over all concentration was $10^{-3} \mathrm{~mol} \mathrm{~L}^{-1}$. Colloid aggregation was induced by addition of an aqueous solution of $\mathrm{MgCl}_{2}$ (1 drop of a $2 \mathrm{~mol} \mathrm{~L}^{-1}$ solution). Polyvinylpyrrolidone was then used to stabilize the colloid (1 drop of $0.1 \mathrm{~g} / 10 \mathrm{~mL}$ aqueous solution). The final colloid mixture was placed in a glass tube and the Raman spectrum registered.

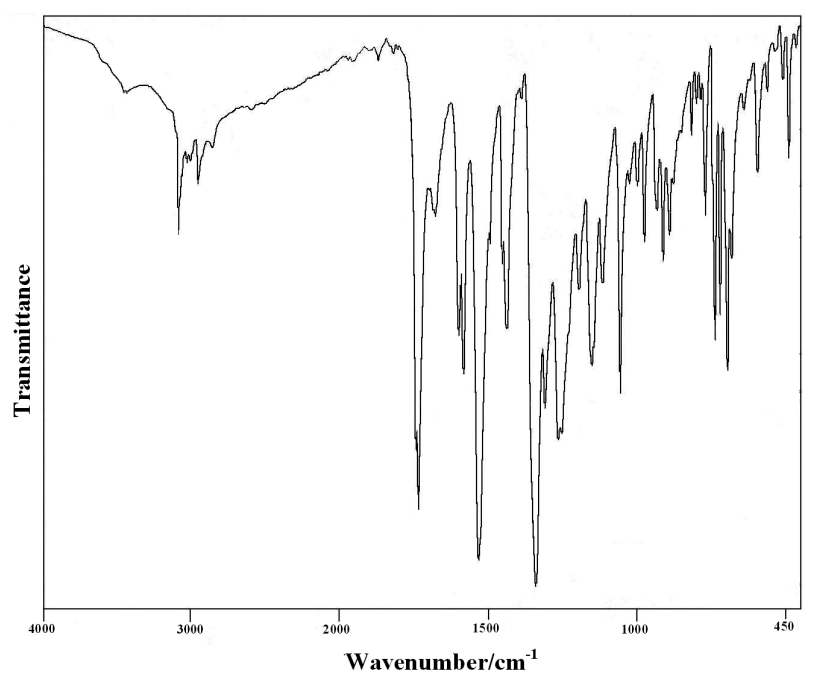

Figure 1. IR spectrum. 


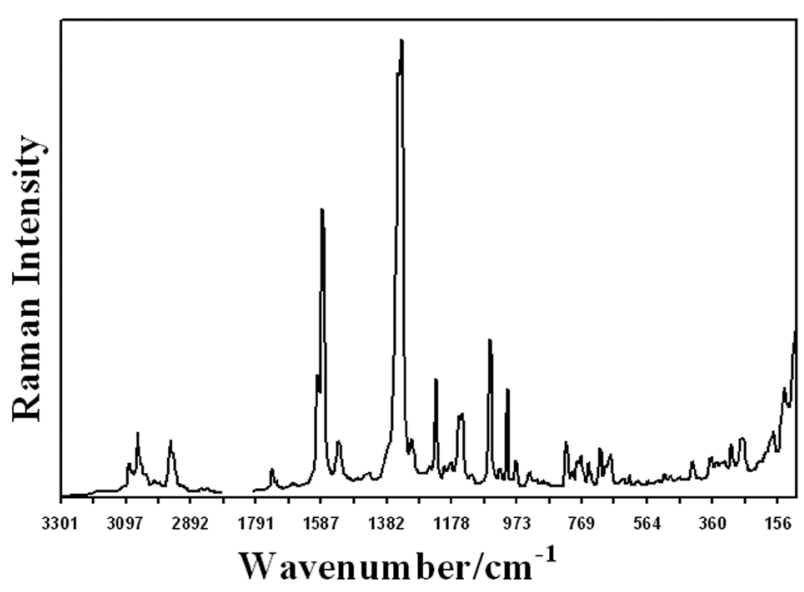

Figure 2. Normal Raman spectrum.

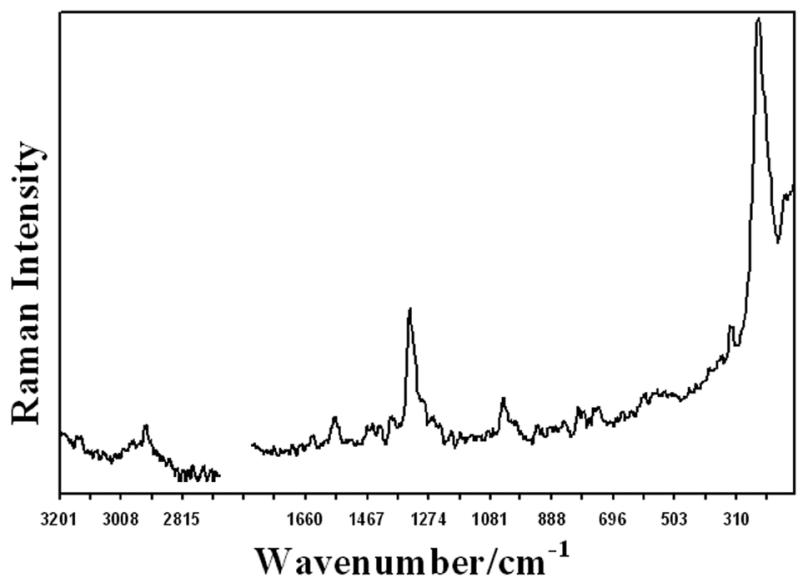

Figure 3. SERS spectrum.

\section{Computational details}

The density Functional Theory (DFT) computations were performed at the B3LYP/6-31G* level theory to get optimized geometry (Figure 4) and vibrational wavenumbers of normal modes of the title compound. DFT calculations were carried out with Becke's three parameters hybrid model using the Lee-Yang-Parr correlation functional (B3LYP) method. Molecular geometries were fully optimized by Berny's optimization algorithm using redundant internal coordinates. Harmonic vibratrional wavaenumbers were calculated using analytic second derivatives to confirm the convergence to minima in the potential surface. At the optimized structure of the examined species, no imaginary wavenumber modes were obtained, proving that a true minimum on the potential surface was found. The optimum geometry (Table S1, Supplementary Information) was determined by minimizing the energy with respect to all geometrical parameters without imposing molecular symmetry constraints. The DFT hybrid B3LYP functional

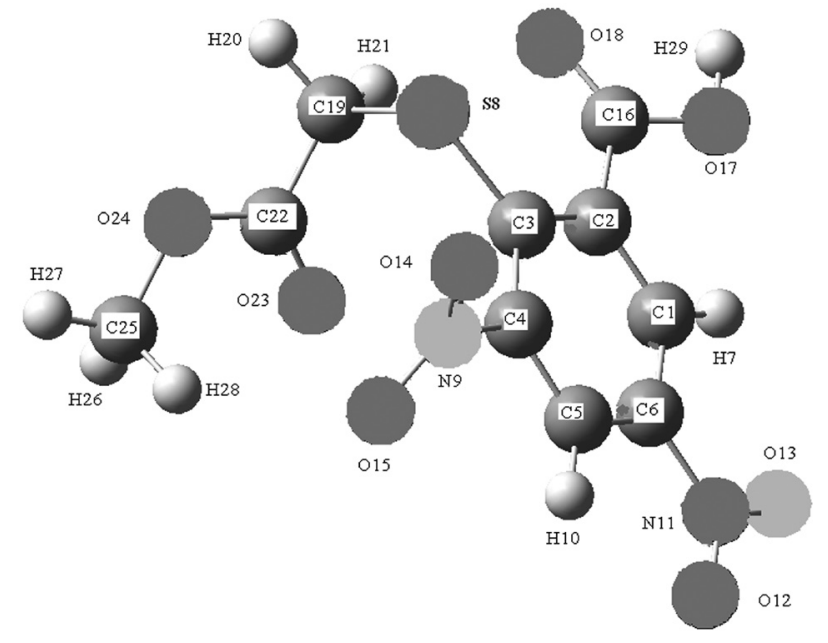

Figure 4. Optimized geometry of the molecule.

tends also to overestimate the fundamental modes, therefore scaling factors have to be used for obtaining a considerable better agreement with experimental data. ${ }^{18,19}$ Thus, a scaling factor of 0.9613 has been uniformly applied to the B3LYP calculated wavenumbers. ${ }^{18}$ The observed disagreement between the theory and the experiment could be a consequence of the anharmonicity and of the general tendency of the quantum chemical methods to overestimate the force constants at the exact equilibrium geometry. ${ }^{20}$ The assignment of the calculated wavenumbers is aided by the animation option of MOLEKEL program, which gives a visual presentation of the vibrational modes..$^{21,22}$

\section{Results and Discussion}

The observed Raman and IR bands with their relative intensities, calculated values and assignments are given in Table 1. The Raman of the solid and the SERS spectrum of 2-(methoxycarbonylmethylsulfanyl)-3,5dinitrobenzenecarboxylic acid are presented in Figures 2 and 3 , respectively.

\section{Carboxylic group vibrations}

Carboxylic acids are best characterized by the $\mathrm{OH}$ stretch, the $\mathrm{C}=\mathrm{O}$ stretch and the $\mathrm{OH}$ out-of-plane deformation. The $\mathrm{C}=\mathrm{O}$ stretching vibration in the spectra of carboxylic acids ${ }^{23}$ give rise to a band in the region $1725 \pm$ $65 \mathrm{~cm}^{-1}$. In the present case, we have observed a band at $1750 \mathrm{~cm}^{-1}$ in the IR spectrum and $1756 \mathrm{~cm}^{-1}$ theoretically. Two bands arising from the $\mathrm{C}-\mathrm{O}$ stretching and $\mathrm{OH}$ bending appear in the spectra of carboxylic acids near $1320-1210 \mathrm{~cm}^{-1}$ and $1440-1395 \mathrm{~cm}^{-1}$, respectively. ${ }^{24}$ Both of these bands involve some interaction between $\mathrm{C}-\mathrm{O}$ stretching and in-plane C-O-H bending. The $v(\mathrm{C}-\mathrm{O})_{c}$ mode 
Table 1. Infrared, Raman and SERS spectral data (wavenumbers in $\mathrm{cm}^{-1}$ ), calculated data and band assignments for 2-(methoxycarbonylmethylsulfanyl)3,5-nitrobenzenecarboxylicacid

\begin{tabular}{|c|c|c|c|c|c|}
\hline Calculated $/\left(\mathrm{cm}^{-1}\right)$ & IR/(KM/Mole $)$ & $\mathrm{IR} /\left(\mathrm{cm}^{-1}\right)$ & $\operatorname{Raman} /\left(\mathrm{cm}^{-1}\right)$ & SERS/ $\left(\mathrm{cm}^{-1}\right)$ & Assignments \\
\hline 3553 & 104.96 & - & - & - & $\mathrm{vOH}$ \\
\hline 3150 & 13.03 & - & - & - & $v \mathrm{CH}$ \\
\hline 3138 & 14.74 & - & - & $3139 \mathrm{vw}$ & $v \mathrm{CH}$ \\
\hline 3075 & 16.51 & $3086 \mathrm{~m}$ & $3087 w$ & - & $\mathrm{v}_{\mathrm{as}} \mathrm{CH}_{2}$ \\
\hline 3068 & 15.06 & - & $3060 \mathrm{~m}$ & - & $\mathrm{v}_{\mathrm{as}} \mathrm{Me}$ \\
\hline 3038 & 4.72 & $3042 \mathrm{vw}$ & - & - & $\mathrm{v}_{\mathrm{as}} \mathrm{Me}$ \\
\hline 2997 & 3.92 & $3000 \mathrm{vw}$ & - & - & $v_{\mathrm{s}} \mathrm{CH}_{2}$ \\
\hline 2962 & 24.40 & $2955 \mathrm{w}$ & $2958 \mathrm{~m}$ & $2933 \mathrm{w}$ & $v_{\mathrm{s}} \mathrm{Me}$ \\
\hline 1756 & 294.05 & $1750 \mathrm{sh}$ & - & - & $v \mathrm{C}=\mathrm{O}$ carboxyl \\
\hline 1744 & 201.61 & 1733 vs & $1741 \mathrm{w}$ & - & $v \mathrm{C}=\mathrm{O}$ methoxy \\
\hline 1609 & 183.04 & $1599 \mathrm{~s}$ & $1600 \mathrm{~s}$ & $1635 \mathrm{vw}$ & $v_{\mathrm{as}} \mathrm{NO}_{2}, \mathrm{vPh}$ \\
\hline 1592 & 164.05 & $1583 \mathrm{~s}$ & $1583 \mathrm{vs}$ & - & $v_{\mathrm{as}} \mathrm{NO}_{2}$ \\
\hline 1568 & 35.73 & - & - & $1567 \mathrm{w}$ & $v_{\mathrm{as}} \mathrm{NO}_{2}, \mathrm{vPh}$ \\
\hline 1546 & 130.61 & 1533 vvs & $1531 \mathrm{~m}$ & - & $v_{\mathrm{as}} \mathrm{NO}_{2}$ \\
\hline 1464 & 6.43 & - & - & $1465 \mathrm{vw}$ & $\delta_{\mathrm{as}} \mathrm{Me}$ \\
\hline 1456 & 6.39 & $1453 \mathrm{~m}$ & - & $1448 \mathrm{vw}$ & $\delta_{\text {as }} \mathrm{Me}, v \mathrm{Ph}$ \\
\hline 1440 & 25.49 & $1439 \mathrm{~m}$ & - & $1427 \mathrm{vw}$ & $\delta_{\mathrm{s}} \mathrm{Me}$ \\
\hline 1431 & 5.06 & - & - & - & $\delta \mathrm{CH}_{2}$ \\
\hline 1410 & 37.62 & - & - & - & $\delta \mathrm{OH}$ \\
\hline 1373 & 1.53 & - & - & $1383 \mathrm{vw}$ & $v \mathrm{Ph}$ \\
\hline 1365 & 92.86 & - & - & - & $\mathrm{v}_{\mathrm{s}} \mathrm{NO}_{2}$ \\
\hline 1344 & 363.64 & $1341 \mathrm{vs}$ & $1345 \mathrm{sh}$ & $1332 \mathrm{~s}$ & $\mathrm{v}_{\mathrm{s}} \mathrm{NO}_{2}$ \\
\hline 1330 & 144.82 & - & 1336 vs & - & vC-O carboxyl \\
\hline 1285 & 153.10 & $1308 \mathrm{~s}$ & $1303 \mathrm{~m}$ & - & $\omega \mathrm{CH}_{2}$ \\
\hline 1278 & 235.82 & $1265 \mathrm{~s}$ & - & $1254 \mathrm{vw}$ & $v \mathrm{C}(=\mathrm{O}) \mathrm{O}$ \\
\hline 1209 & 37.85 & $1195 \mathrm{~m}$ & $1228 \mathrm{~s}$ & - & $\omega \mathrm{CH}_{2}$ \\
\hline 1179 & 118.03 & - & - & $1188 \mathrm{vw}$ & $\delta \mathrm{CH}$ \\
\hline 1173 & 4.68 & - & - & $1171 \mathrm{vw}$ & $\delta \mathrm{CH}$ \\
\hline 1173 & 86.95 & $1152 \mathrm{~s}$ & $1156 \mathrm{~m}$ & - & $\rho \mathrm{Me}$ \\
\hline 1142 & 0.95 & - & $1145 \mathrm{~m}$ & - & $\rho \mathrm{Me}$ \\
\hline 1121 & 148.83 & $1115 \mathrm{~m}$ & - & - & $\tau \mathrm{CH}_{2}$ \\
\hline 1107 & 192.66 & - & - & - & $\tau \mathrm{CH}_{2}$ \\
\hline 1092 & 156.39 & $1056 \mathrm{~s}$ & $1058 \mathrm{~s}$ & $1041 \mathrm{~m}$ & $\delta \mathrm{CH}$ \\
\hline 1025 & 43.33 & - & $1004 \mathrm{~s}$ & - & Ring breathing \\
\hline 999 & 27.44 & $998 \mathrm{w}$ & $977 \mathrm{w}$ & - & $v \mathrm{O}-\mathrm{C}(\mathrm{Me})$ \\
\hline 928 & 10.53 & $933 \mathrm{w}$ & $935 \mathrm{vw}$ & $938 \mathrm{vw}$ & $\gamma \mathrm{CH}$ \\
\hline 922 & 4.65 & - & - & - & $\gamma \mathrm{CH}$ \\
\hline 913 & 22.62 & $912 \mathrm{w}$ & - & - & $v \mathrm{C}-\mathrm{N}$ \\
\hline 906 & 22.83 & - & - & - & $\gamma \mathrm{CH}$ \\
\hline 877 & 11.89 & $890 \mathrm{w}$ & - & - & $v \mathrm{C}-\mathrm{N}, \mathrm{vCC}$ carboxyl \\
\hline 832 & 3.39 & $816 \mathrm{vw}$ & $819 w$ & - & $\rho \mathrm{CH}_{2}$ \\
\hline 775 & 16.29 & $800 \mathrm{vw}$ & $784 \mathrm{w}$ & $804 \mathrm{~m}$ & $\delta \mathrm{NO}_{2}$ \\
\hline 772 & 19.01 & $770 \mathrm{w}$ & $775 \mathrm{w}$ & - & $\delta \mathrm{C}=\mathrm{O}$ carboxyl \\
\hline
\end{tabular}


Table 1. continuation

\begin{tabular}{|c|c|c|c|c|c|}
\hline Calculated $/\left(\mathrm{cm}^{-1}\right)$ & IR/(KM/Mole) & $\mathrm{IR} /\left(\mathrm{cm}^{-1}\right)$ & $\operatorname{Raman} /\left(\mathrm{cm}^{-1}\right)$ & SERS $/\left(\mathrm{cm}^{-1}\right)$ & Assignments \\
\hline 765 & 1.05 & - & $748 \mathrm{w}$ & - & $\delta \mathrm{C}=\mathrm{O}$ methoxy \\
\hline 740 & 85.93 & $737 \mathrm{~s}$ & - & $741 \mathrm{w}$ & $\delta \mathrm{NO}_{2}$ \\
\hline 722 & 28.54 & $721 \mathrm{~m}$ & - & - & $\omega \mathrm{NO}_{2}$ \\
\hline 720 & 29.56 & - & - & - & $\omega \mathrm{NO}_{2}$ \\
\hline 709 & 111.08 & $696 \mathrm{~s}$ & $713 \mathrm{w}$ & - & $\gamma \mathrm{Ph}$ \\
\hline 667 & 13.25 & $682 \mathrm{w}$ & $680 \mathrm{w}$ & - & $v \mathrm{C}-\mathrm{S}, \gamma \mathrm{C}=\mathrm{O}$ methoxy \\
\hline 635 & 84.06 & - & - & - & $\gamma \mathrm{C}=\mathrm{O}$ carboxyl \\
\hline 617 & 61.99 & $615 \mathrm{w}$ & - & - & $\gamma \mathrm{OH}$ \\
\hline 597 & 28.31 & $594 \mathrm{w}$ & - & $593 \mathrm{vw}$ & $\delta \mathrm{Ph}(\mathrm{X})$ \\
\hline 574 & 5.21 & - & - & - & $\delta \mathrm{Ph}(\mathrm{X})$ \\
\hline 561 & 17.41 & $562 \mathrm{w}$ & - & $554 \mathrm{vw}$ & $\gamma \mathrm{Ph}$ \\
\hline 523 & 3.83 & $509 \mathrm{vw}$ & - & - & $\rho \mathrm{NO}_{2}$ \\
\hline 489 & 3.20 & $489 w$ & - & - & $\mathrm{\rho NO}_{2}$ \\
\hline 477 & 8.47 & - & - & - & $\gamma \mathrm{Ph}(\mathrm{X})$ \\
\hline 409 & 1.64 & - & $422 \mathrm{w}$ & - & $\rho C(=O)-O$ \\
\hline 382 & 8.61 & - & - & $397 \mathrm{vw}$ & $\gamma \mathrm{Ph}(\mathrm{X})$ \\
\hline 364 & 1.04 & - & - & $354 \mathrm{w}$ & $\gamma \mathrm{Ph}(\mathrm{X})$ \\
\hline 335 & 2.88 & - & - & $327 \mathrm{~m}$ & Skel. C-O-C \\
\hline 313 & 0.45 & - & $302 \mathrm{w}$ & - & $\gamma \mathrm{Ph}(\mathrm{X})$ \\
\hline 300 & 5.51 & - & - & - & $\gamma \mathrm{Ph}(\mathrm{X})$ \\
\hline 283 & 9.53 & - & - & - & $\delta \mathrm{Ph}(\mathrm{X})$ \\
\hline 278 & 11.61 & - & $271 \mathrm{w}$ & - & $\mathrm{tMe}$ \\
\hline - & 4.38 & - & - & 241 vs & $v A g-O$ \\
\hline 232 & 0.31 & - & - & - & $\mathrm{tMe}$ \\
\hline 207 & 0.60 & - & - & - & $\mathrm{tPh}$ \\
\hline 168 & 0.50 & - & $169 \mathrm{w}$ & - & $\mathrm{tMe}$ \\
\hline 162 & 2.38 & - & - & - & $\mathrm{tPh}$ \\
\hline 157 & 2.88 & - & - & - & $\mathrm{tMe}$ \\
\hline 145 & 0.78 & - & - & - & $\mathrm{tPh}$ \\
\hline 139 & 3.68 & - & $134 \mathrm{~m}$ & - & $\mathrm{tPh}$ \\
\hline 121 & 3.03 & - & - & - & $\mathrm{tMe}$ \\
\hline 108 & 0.78 & - & $110 \mathrm{~m}$ & - & $\mathrm{tMe}$ \\
\hline 63 & 0.18 & - & - & - & $\mathrm{tNO}_{2}$ \\
\hline 59 & 0.203 & - & - & - & $\mathrm{tNO}_{2}$ \\
\hline 52 & 0.86 & - & - & - & $\mathrm{tNO}_{2}$ \\
\hline 45 & 0.56 & - & - & - & $\mathrm{tNO}_{2}$ \\
\hline 35 & 1.70 & - & - & - & $\mathrm{tPh}$ \\
\hline 29 & 0.48 & - & - & - & $\mathrm{tCH}_{3}$ \\
\hline 18 & 0.78 & - & - & - & $\mathrm{tCH}_{2}$ \\
\hline
\end{tabular}

$v$-stretching; $\delta$-in-plane deformation; $\gamma$-out-of-plane deformation; $\rho$-rocking; $\tau$-twisting; $\omega$-wagging; t-torsion; s-strong; b-broad; v-very; w-weak; Me-methyl; Ph-phenyl; X-substituent sensitive; m-medium. 
is reported at $1377 \mathrm{~cm}^{-1}$ for sodium salicylate, ${ }^{25}$ at $1391 \mathrm{~cm}^{-1}$ for 4-aminosalicylic acid $^{26}$ and at 1375 (IR), $1382 \mathrm{~cm}^{-1}$ (HF) for 3,5-dinitrosalicylic acid. ${ }^{27}$ For the title compound, the band observed at $1330 \mathrm{~cm}^{-1}$ (DFT) and $1336 \mathrm{~cm}^{-1}$ (Raman) is assigned as $v(\mathrm{C}-\mathrm{O})_{c}$ mode.

\section{Methoxycarbonyl group vibrations}

In the spectra of methyl esters the overlap of the regions in which both asymmetric stretching ${ }^{23} v_{\text {as }}$ Me absorb with a weak to strongly $\left(3020 \pm 30\right.$ and $\left.2990 \pm 40 \mathrm{~cm}^{-1}\right)$ is not large and regularly seen above $3000 \mathrm{~cm}^{-1}$. The computed wavenumbers of modes corresponding to the $v_{\text {as }} \mathrm{Me}$ group are 3068 and $3038 \mathrm{~cm}^{-1}$. For the title compound, bands observed at $3060 \mathrm{~cm}^{-1}$ in the Raman spectrum and $3042 \mathrm{~cm}^{-1}$ in the IR spectrum are assigned as asymmetric methyl stretching vibrations. The symmetric stretching mode $v_{c}$ Me is expected in the range $2920 \pm 80 \mathrm{~cm}^{-1}$ in which all the $\mathrm{CH}$ bonds extend and contract in phase. ${ }^{23}$ The bands at 2955 (IR), 2958 (Raman) and $2962 \mathrm{~cm}^{-1}$ (DFT) are assigned as this mode. Panicker et al..$^{14}$ reported the stretching vibrations of methyl group at 3068, 3038, 2963 (DFT), 2961 (IR) and $2962 \mathrm{~cm}^{-1}$ (Raman) for methyl stretching vibrations. The stretching vibrations of the methyl group are reported at 3016, 2967, $2857 \mathrm{~cm}^{-1}$ (IR), 3046, 2962, $2842 \mathrm{~cm}^{-1}$ (Raman), $3171,3137,3058 \mathrm{~cm}^{-1}$ (DFT) for methoxycarbonylsulfenyl isocyanate and $^{5} 3014,2966,2850 \mathrm{~cm}^{-1}$ (IR), 3039, 2959, $2840 \mathrm{~cm}^{-1}$ (Raman), 3191, 3159, $3073 \mathrm{~cm}^{-1}$ (DFT) for methoxycarbonylsulfenyl chloride. ${ }^{4}$

Two bending vibrations can occur within a methyl group. The first of these, the symmetric bending vibration $\delta_{s} \mathrm{Me}$ involves the in-phase bending of the $\mathrm{C}-\mathrm{H}$ bonds. The second, the asymmetrical bending mode $\delta_{\text {as }}$ Me involves out-of-phase bending of the $\mathrm{C}-\mathrm{H}$ bonds. ${ }^{24}$ The asymmetric bending vibrations of the methoxy group ${ }^{23}$ normally appears in the regions $1460 \pm 25$ and $1450 \pm 15 \mathrm{~cm}^{-1}$ and the symmetric vibrations mostly displayed in the range $1435 \pm$ $15 \mathrm{~cm}^{-1}$. The intensity of these vibrations is only weak to moderate. In the spectra of $\mathrm{H}_{2} \mathrm{NC}(=\mathrm{O}) \mathrm{OMe}$ and $\mathrm{Cl}_{2} \mathrm{NC}(=\mathrm{O})$ $\mathrm{OMe}$, the symmetric deformation $\delta_{\mathrm{s}} \mathrm{Me}$ is reported at 1369 and $1386 \mathrm{~cm}^{-1}$, respectively. ${ }^{23}$ The DFT calculations give 1464,1456 and $1440 \mathrm{~cm}^{-1}$ as $\delta_{\text {as }} \mathrm{Me}$ and $\delta_{\mathrm{s}} \mathrm{Me}$, respectively, for the title compound. The bands observed at 1453 and $1439 \mathrm{~cm}^{-1}$ in the IR spectrum are assigned to these modes. For methyl (2-methyl-4,6-dinitrophenyl sulfanyl) ethanoate ${ }^{14}$ the bending vibrations of the methyl group are reported at 1464, 1455, 1375 (DFT), 1376 (Raman) and $1371 \mathrm{~cm}^{-1}$ (IR). For methoxycarbonylsulfenyl compounds, the bending modes of the methyl group are reported at 1465, $1454,1453,1450,1437,1436,1435,1428,1302 \mathrm{~cm}^{-1}$ in IR, $1452,1329 \mathrm{~cm}^{-1}$ in Raman, 1499, 1488, $1470 \mathrm{~cm}^{-1}(\mathrm{DFT})^{4}$ and at $1443,1436,1368 \mathrm{~cm}^{-1}$ in IR, $1450,1410 \mathrm{~cm}^{-1}$ in Raman, 1495, 1484, $1468 \mathrm{~cm}^{-1}$ (DFT). ${ }^{5}$

The methyl rock $\rho$ Me has been observed at $1185 \pm$ $35 \mathrm{~cm}^{-1}$ often as a shoulder on the low wavenumber wing of $\mathrm{vC}(=\mathrm{O}) \mathrm{O}$ absorption. ${ }^{23} \mathrm{In} i$ - $\mathrm{PrC}(=\mathrm{O}) \mathrm{O}-\mathrm{OMe}$ this mode $\left(1194 \mathrm{~cm}^{-1}\right)$ is next to $\mathrm{vC}(=\mathrm{O}) \mathrm{O}\left(1202 \mathrm{~cm}^{-1}\right)$ but $t-\mathrm{BuC}(=\mathrm{O})$ OMe both absorptions ${ }^{23}$ coincide at $1193 \mathrm{~cm}^{-1}$. The second methyl rock ${ }^{23}$ absorbs at $1155 \pm 35 \mathrm{~cm}^{-1}$. The bands calculated at 1173 and $1142 \mathrm{~cm}^{-1}$ are assigned as rocking modes of the methyl group. Experimentally the bands observed at $1152 \mathrm{~cm}^{-1}$ in the IR spectrum and at $1156,1145 \mathrm{~cm}^{-1}$ in the Raman spectrum are assigned rocking modes of the methyl group. The methyl rocking modes are reported at $1195,1171 \mathrm{~cm}^{-1}$ in IR, $1193,1148 \mathrm{~cm}^{-1}$ in Raman, 1212 , $1181,1167 \mathrm{~cm}^{-1}(\text { DFT) })^{5}$ and at $1194,1190 \mathrm{~cm}^{-1}$ in IR, $1196 \mathrm{~cm}^{-1}$ in Raman, $1211 \mathrm{~cm}^{-1}$ (DFT). ${ }^{4}$

The most characteristic bands of esters arising from the $\mathrm{C}=\mathrm{O}$ stretching vibration occurring at $1750 \pm 50 \mathrm{~cm}^{-1}$ with a strong to very strong intensity. ${ }^{23}$ Methyl esters of $\alpha$-unsaturated and aromatic carboxylic acids ${ }^{23}$ show the $v \mathrm{C}=\mathrm{O}$ at $1725 \pm 25 \mathrm{~cm}^{-1}$. Seth Paul and Van Duyse ${ }^{28}$ identified the region $1730 \pm 15 \mathrm{~cm}^{-1}$ for mono- and disubstituted methyl benzoates and Nyquist ${ }^{29}$ proposed $1733 \pm 5 \mathrm{~cm}^{-1}$ for $o$-phtalic esters. The intensity of the carbonyl stretching band can increase owing to conjugation, or formation of hydrogen bonds. The increase in conjugation, therefore leads the intensification of the Raman lines and increase IR band intensities. The stretching modes of the carbonyl group of the ester part may be lowered to around $1720 \mathrm{~cm}^{-1}$ in the presence of conjugation. ${ }^{30} \mathrm{In}$ the present study the $\mathrm{vC}=\mathrm{O}$ mode is seen at $1733 \mathrm{~cm}^{-1}$ in IR, $1741 \mathrm{~cm}^{-1}$ in Raman and $1744 \mathrm{~cm}^{-1}$ theoretically. For methoxycarbonylsulfenyl compounds, $\mathrm{vC}=\mathrm{O}$ is reported at 1772 (DFT), 1779 (IR), $1756 \mathrm{~cm}^{-1}$ (Raman) ${ }^{4}$ and at 1788 (DFT), 1750 (IR), $1734 \mathrm{~cm}^{-1}$ (Raman). ${ }^{5}$

The $\mathrm{C}(=\mathrm{O}) \mathrm{O}$ stretching vibration, often considered as the C-O-C asymmetric stretch, appears strongly at $1255 \pm$ $60 \mathrm{~cm}^{-1}$, a region in good agreement with that of the $v C-O$ in carboxylic acids $\left(1250 \pm 80 \mathrm{~cm}^{-1}\right){ }^{23}$ The band at $1265 \mathrm{~cm}^{-1}$ in IR spectrum is assigned as the $\mathrm{VC}-\mathrm{O}-\mathrm{C}$ mode and the calculated value of this mode is $1278 \mathrm{~cm}^{-1}$. The O-C stretching vibration of the $\mathrm{O}-\mathrm{CH}_{3}$ group, coupled with the methyl rock, appears in the wide region $975 \pm 125 \mathrm{~cm}^{-1}$ with an intensity varying from weak to strong..$^{23}$ This vibration is often called the symmetric COC stretching vibration. The band at $999 \mathrm{~cm}^{-1}$ given by DFT calculation is assigned as this mode. Erban et $_{\text {al }}{ }^{4}$ reported the $\mathrm{VOC}$ stretching mode at 963 (DFT), $977 \mathrm{~cm}^{-1}$ (IR), $937 \mathrm{~cm}^{-1}$ (Raman) and Vallejos et al. ${ }^{5}$ reported this mode at 940 (Raman), $959 \mathrm{~cm}^{-1}$ (DFT).

The $\delta \mathrm{C}=\mathrm{O}$ deformation ${ }^{23}$ has been found in the region $710 \pm 80 \mathrm{~cm}^{-1}$ and the band at 748 (Raman), $765 \mathrm{~cm}^{-1}$ 
(DFT) is assigned as this mode. The $\gamma \mathrm{C}=\mathrm{O}$ absorption $^{23}$ is in the range $625 \pm 75 \mathrm{~cm}^{-1}$ and the DFT calculation give this mode at $667 \mathrm{~cm}^{-1}$. The $\mathrm{C}-\mathrm{C}(=\mathrm{O})-\mathrm{O}$ deformation ${ }^{23}$ rock absorbs weakly to moderately in the region $435 \pm 95 \mathrm{~cm}^{-1}$. For most of the methyl esters give the region $445 \pm 60 \mathrm{~cm}^{-1}$ for this rock. Methyl acetate absorbs at $435 \mathrm{~cm}^{-1}$ and methyl propanoate at $440 \mathrm{~cm}^{-1} .{ }^{23}$ Saunders et al. ${ }^{31}$ found $445 \pm$ $10 \mathrm{~cm}^{-1}$ as $\mathrm{C}-\mathrm{C}(=\mathrm{O})-\mathrm{O}$ deformation for a series of fourteen aliphatic methyl esters. The DFT calculations give this mode at $409 \mathrm{~cm}^{-1}$ and a weak band is observed at $422 \mathrm{~cm}^{-1}$ in the Raman spectrum. The skeletal C-O-C deformation ${ }^{23}$ appears in the region $325 \pm 40 \mathrm{~cm}^{-1}$. For methyl formate and methyl acetate this mode is at 330 and $318 \mathrm{~cm}^{-1}$, respectively. ${ }^{23}$ Saunders et al..$^{31}$ found $330 \pm 15 \mathrm{~cm}^{-1}$ for a series of aliphatic methyl esters. For the title compound this C-O-C deformation is found at $335 \mathrm{~cm}^{-1}$.

\section{Nitro group vibrations}

The most characteristic bands in the spectra of nitro compounds are due to the $\mathrm{NO}_{2}$ stretching vibrations, which are the two most useful group wavenumbers, not only because of their spectral positions but also for their strong intensities. ${ }^{23}$ Nitrobenzene derivatives display $\mathrm{v}_{\mathrm{as}} \mathrm{NO}_{2}$ in the regions $1535 \pm 30 \mathrm{~cm}^{-1}$ and 3-nitropyridines at $1530 \pm$ $20 \mathrm{~cm}^{-1} .^{23,32}$ The authors have reported bands at 1604, 1583, $1538 \mathrm{~cm}^{-1}$ (Raman), 1604, 1582, 1532 (IR) and $1605,1588,1565,1544 \mathrm{~cm}^{-1}$ (DFT) as $\mathrm{v}_{\text {as }} \mathrm{NO}_{2}$ modes. ${ }^{14}$ The bands seen at $1583,1531 \mathrm{~cm}^{-1}$ in the Raman spectrum and $1599,1583,1533 \mathrm{~cm}^{-1}$ in the IR spectrum are assigned as $\mathrm{v}_{\text {as }} \mathrm{NO}_{2}$ for the title compound. The calculated values for these modes are 1609, 1592, 1568 and $1546 \mathrm{~cm}^{-1}$. In substituted nitrobenzenes ${ }^{23,32} \mathrm{v}_{\mathrm{s}} \mathrm{NO} 2$ appears strongly at $1345 \pm 30 \mathrm{~cm}^{-1}$, in 3-nitropyridine at $1350 \pm 20 \mathrm{~cm}^{-1}$, and in conjugated nitroalkenes ${ }^{33}$ at $1345 \pm 15 \mathrm{~cm}^{-1}$. Panicker et al. ${ }^{14}$ reported 1346 (Raman), 1344 (IR) and 1348, $1339 \mathrm{~cm}^{-1}$ (DFT) as $\mathrm{v}_{\mathrm{s}} \mathrm{NO}_{2}$ modes. The band at $1341 \mathrm{~cm}^{-1}$ in IR spectrum, $1345 \mathrm{~cm}^{-1}$ in Raman spectrum and 1365 , $1344 \mathrm{~cm}^{-1}$ (calculated) are assigned as $\mathrm{v}_{\mathrm{s}} \mathrm{NO}_{2}$ modes. The $\mathrm{NO}_{2}$ scissors occur at higher wavaenumbers $\left(850 \pm 60 \mathrm{~cm}^{-1}\right)$ when conjugated to $\mathrm{C}=\mathrm{C}$ or aromatic molecules. ${ }^{34,35}$ In aromatic compounds the wagging mode $\omega_{\mathrm{NO}}$ is assigned at $740 \pm 50 \mathrm{~cm}^{-1}$ with a moderate to strong intensity. ${ }^{23}$ The bands at $784 \mathrm{~cm}^{-1}$ in the Raman spectrum, $800,737 \mathrm{~cm}^{-1}$ in the IR spectrum and $775,740 \mathrm{~cm}^{-1}$ (DFT) are assigned as the deformation bands of nitro groups. The DFT calculations give the wagging modes $\omega_{2} \mathrm{NO}_{2}$ at 722 and $720 \mathrm{~cm}^{-1}$. The rocking mode $\mathrm{\rho NO}_{2}$ is active in the region $540 \pm 70 \mathrm{~cm}^{-1}$ in aromatic nitro compounds. ${ }^{23}$ Varsanyi et al. ${ }^{36}$ found $70 \pm$ $20 \mathrm{~cm}^{-1}$ and Suryanarayana et al. ${ }^{37}$ found $65 \pm 10 \mathrm{~cm}^{-1}$ as the torsion of the $\mathrm{NO}_{2}$ for aromatic compounds.

\section{$\mathrm{CH}_{2}$ group vibrations}

The vibrations of the $\mathrm{CH}_{2}$ group, the asymmetric stretch $\mathrm{v}_{\text {as }} \mathrm{CH}_{2}$, symmetric stretch $\mathrm{v}_{\mathrm{s}} \mathrm{CH}_{2}$, scissoring vibration $\delta \mathrm{CH}_{2}$ and wagging vibration $\omega \mathrm{CH}_{2}$ appear in the regions $3000 \pm 50,2965 \pm 30,1455 \pm 55$ and $1350 \pm 85 \mathrm{~cm}^{-1}$, respectively. ${ }^{23,38}$ The DFT calculation give $\mathrm{v}_{\text {as }} \mathrm{CH}_{2}$ at 3075 and $v_{\mathrm{s}} \mathrm{CH}_{2}$ at $2997 \mathrm{~cm}^{-1}$. The $\mathrm{CH}_{2}$ deformation band which comes near $1463 \mathrm{~cm}^{-1}$ in alkenes ${ }^{39}$ is lowered to about $1440 \mathrm{~cm}^{-1}$ when the $\mathrm{CH}_{2}$ group is next to a double or triple bond. A carbonyl, nitrile or nitro group each lowers the wavenumber of the adjacent $\mathrm{CH}_{2}$ group ${ }^{38}$ to about $1425 \mathrm{~cm}^{-1}$. For the title compound the DFT calculation give 1431, 1209, 1121 and $1107 \mathrm{~cm}^{-1}$ as the deformation bands of $\mathrm{CH}_{2}$ group. The rocking mode ${ }^{23} \rho \mathrm{CH}_{2}$ is expected in the range $895 \pm 85 \mathrm{~cm}^{-1}$ and the band at 832 (DFT), 816 (IR) and $819 \mathrm{~cm}^{-1}$ (Raman) are assigned as $\mathrm{\rho CH}_{2}$ modes. The torsional modes of methyl, $\mathrm{CH}_{2}$ and nitro group are seen in the low wavenumber region. ${ }^{23}$

\section{Phenyl ring and other vibrations}

In poly substituted benzenes, the aromatic $\mathrm{CH}$ stretching vibrations ${ }^{23,40}$ absorb weakly to moderately between 3000 and $3120 \mathrm{~cm}^{-1}$. The DFT calculations give bands at 3150 and $3138 \mathrm{~cm}^{-1}$. The aromatic $\mathrm{CH}$ out-of-plane deformation ${ }^{23}$ are observed in the range $720-1000 \mathrm{~cm}^{-1}$. The spectral positions of the weaker $\gamma \mathrm{CH}$ near $900 \mathrm{~cm}^{-1}$ correlates well with electron donating or electron attracting properties of the substituent. The $\mathrm{CH}$ in-plane deformations $\delta \mathrm{CH}$ are obtained at $1056 \mathrm{~cm}^{-1}$ in the IR spectrum and at $1058 \mathrm{~cm}^{-1}$ in the Raman spectrum. The DFT calculation gave 1179, 1173 and $1092 \mathrm{~cm}^{-1}$ as these modes. The out-of-plane deformations and in-plane deformation of the phenyl ring ${ }^{23}$ are observed below $1000 \mathrm{~cm}^{-1}$ and these modes are not pure but contain a significant contribution from other modes and are substituent sensitive. The ring breathing mode appears as a weak band near $1000 \mathrm{~cm}^{-1}$, in mono-, 1,3-di- and 1,3,5-tri substituted benzenes. ${ }^{23}$ In the otherwise substituted benzenes however, this vibration is substituent sensitive and difficult to distinguish from the ring in-plane deformation. ${ }^{23}$ For the title compound the ring breathing mode appears as a strong band at $1004 \mathrm{~cm}^{-1}$ in the Raman spectrum, and at $1025 \mathrm{~cm}^{-1}$ theoretically. Aromatic nitro compounds show a C-N stretching vibration ${ }^{24,41}$ near $870 \mathrm{~cm}^{-1}$. In the present study, the $\mathrm{VCN}$ is 890 and $912 \mathrm{~cm}^{-1}$ in the IR spectrum.

For the title compound the bond lengths $\mathrm{C}_{22}-\mathrm{O}_{23}, \mathrm{C}_{22}-\mathrm{O}_{24}$, and $\mathrm{C}_{25}-\mathrm{O}_{24}$ are found to be $1.2139,1.3429$ and $1.4418 \AA$, respectively. For methoxycarbonylsulfenyl compounds, the reported values of bond lengths are $\mathrm{C}_{22}-\mathrm{O}_{23}=1.1962$ (XRD), 1.2 (DFT), $1.215 \AA$ (MP2), ${ }^{5}$ 1.19(XRD), 1.202 


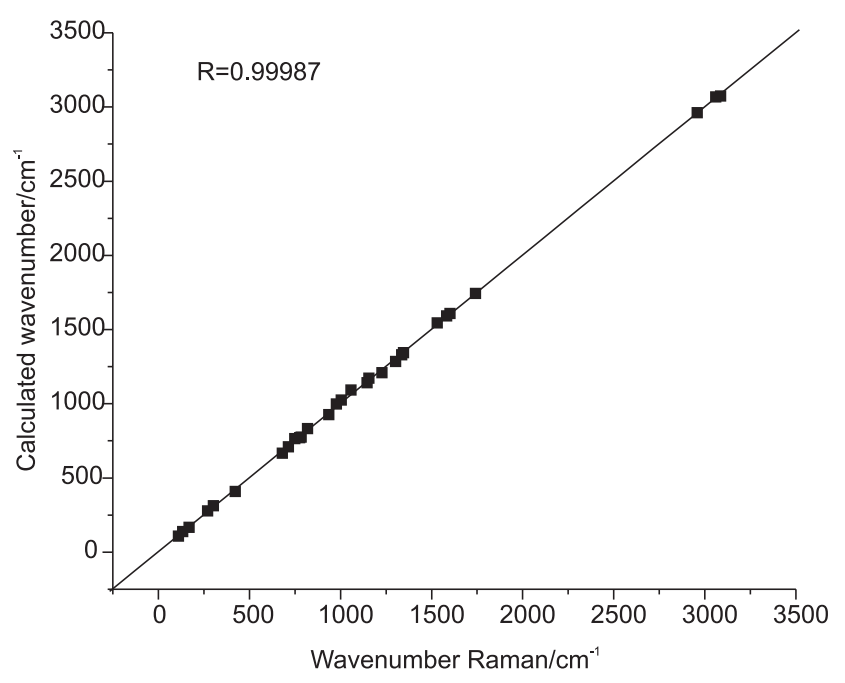

Figure 5. Correlation graphs.

(DFT), $1.199 \AA(\mathrm{MP} 2)^{4}$ and $\mathrm{C}_{22}-\mathrm{O}_{24}=1.3249(\mathrm{XRD})$, 1.341(DFT), $1.34 \AA$ (MP2) and $\mathrm{C}_{22}-\mathrm{O}_{24}=1.4587$ (XRD), $1.449 \AA$ (DFT, MP2). ${ }^{4}$ For the title compound, the bond angles $\mathrm{O}_{23}-\mathrm{C}_{22}-\mathrm{O}_{24}, \mathrm{C}_{22}-\mathrm{O}_{24}-\mathrm{C}_{25}$ are 124.5 and $115.3^{\circ}$, respectively, while the reported values are 127.3 and $115.8^{\circ}$, respectively. ${ }^{4}$ In the present case, the carbon-sulfur bond lengths $\mathrm{C}_{3}-\mathrm{S}_{8}=1.7949$ and $\mathrm{C}_{19}-\mathrm{S}_{8}=1.8493 \AA$ while the reported values are 1.7846 (XRD), 1.792 (MP2) $1.811 \AA$ $(\mathrm{DFT})^{4}$ and 1.771 (XRD), 1.803 (DFT), $1.783 \AA$ (MP2). ${ }^{5}$ The carbon-oxygen distances unambiguously define the single and double bonds in the carboxylate group $\left(\mathrm{C}_{16}-\mathrm{O}_{17}=\right.$ 1.3546 and $\mathrm{C}_{16}-\mathrm{O}_{18}=1.2119 \AA$ ) and are in agreement with the values given by $\mathrm{Ng}$ et al. ${ }^{42}$ The aromatic ring of the title compound is somewhat irregular and the spread of bond distances is $1.3865-1.4199 \AA$, which is similar to the spread reported by Smith et al. ${ }^{12}$

The DFT calculation gives shortening of angle $\mathrm{C}_{4}-\mathrm{C}_{3}-\mathrm{S}_{8}$ by $1.6^{\circ}$ and increase of angle $\mathrm{C}_{2}-\mathrm{C}_{3}-\mathrm{S}_{8}$ by $5^{\circ}$ from $120^{\circ}$ at $\mathrm{C}_{3}$ position and this asymmetry of exocyclic angles reveal the repulsion between carboxylic group and the phenyl ring. ${ }^{43}$ The reduction in the angle $\mathrm{C}_{19}-\mathrm{C}_{22}-\mathrm{O}_{24}$ to $111.8^{\circ}$ from $120^{\circ}$ is associated with repulsive interactions, repulsion between methyl and $\mathrm{O}_{23}$, which is evident from the enlargement in the angle $\mathrm{O}_{23}-\mathrm{C}_{22}-\mathrm{O}_{24}$ by $4.5^{\circ}$. Similar repulsion leads to enlargement of $\mathrm{C}_{19}-\mathrm{C}_{22}-\mathrm{O}_{23}$ by $3.6^{\circ}$. The angle $\mathrm{C}_{22}-\mathrm{O}_{24}-\mathrm{C}_{25}$ is reduced by $4.7^{\circ}$ due to the repulsion between the two lone pairs of $\mathrm{O}_{24}$ and the neighboring atoms. DFT calculations give the shortening of the angle $\mathrm{C}_{5}-\mathrm{C}_{4}-\mathrm{N}_{9}$ by $4.8^{\circ}$ and the increase of angle $\mathrm{C}_{3}-\mathrm{C}_{4}-\mathrm{N}_{9}$ by $1.1^{\circ}$ from $120^{\circ}$ at $\mathrm{C}_{4}$ position and this asymmetry of exocyclic angle, reveal the hydrogen bonding with $\mathrm{H}_{10}$, which is evident from the enlargement in the angle $\mathrm{C}_{5}-\mathrm{C}_{4}-\mathrm{C}_{3}$ by $3.8^{\circ}$. At $\mathrm{C}_{6}$ position the exocylic angles are nearly the same. For a molecule containing a methoxy group, electronic charge is back-donated from the

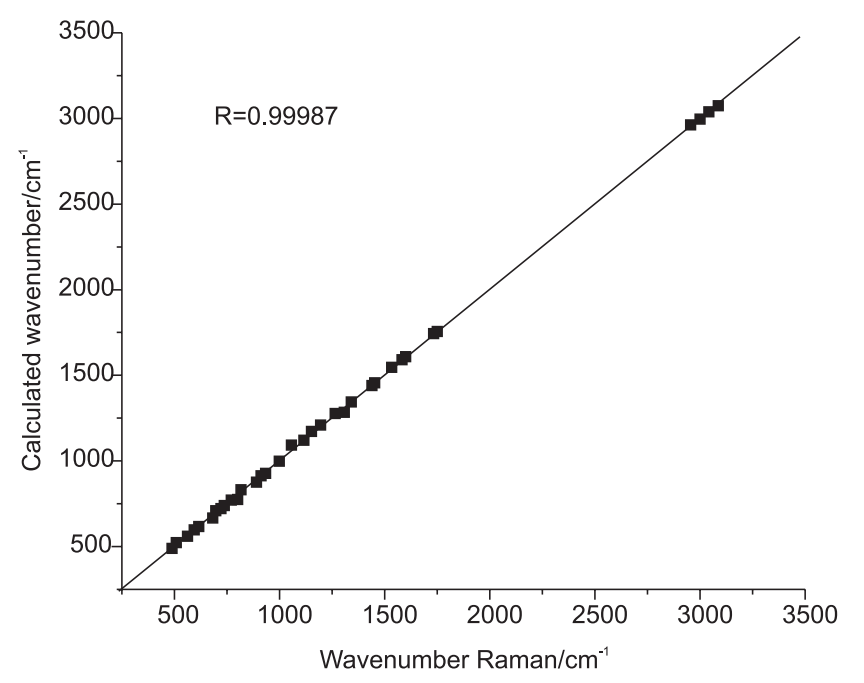

lone pair of oxygen atom to the $\sigma^{*}$ orbital of $\mathrm{C}-\mathrm{H}$ bonds, causing a weakening of the $\mathrm{C}-\mathrm{H}$ bonds. ${ }^{44}$ This is followed by the increase in $\mathrm{C}-\mathrm{H}$ bond distance and the decrease in $\mathrm{C}-\mathrm{H}$ force constants and can result in the enhancement of IR band intensities of the $\mathrm{C}-\mathrm{H}$ stretching modes.$^{45}$ Another electronic effect, induction, produces stronger polarization of $\mathrm{C}-\mathrm{H}$ bonds along with an increase in $\mathrm{C}-\mathrm{H}$ force constant and charge on the hydrogen atom and with a decrease in $\mathrm{C}-\mathrm{H}$ bond length. ${ }^{45}$ In the title compound, the methoxy hydrogen atoms are subjected to induction, which cause a decrease in the $\mathrm{C}-\mathrm{H}$ bond length.

In order to investigate the performance and vibrational wavenumbers of the title compound, root mean square (RMS) and correlation coefficient between calculated (Figure 5) and observed vibrational wavenumbers were calculated. RMS values of wavenumbers were calculated using the following expression. ${ }^{46}$

$$
R M S=\sqrt{\frac{1}{n-1} \sum_{i}^{n}\left(v_{i}^{\text {calc }}-v_{i}^{\exp }\right)^{2}}
$$

The RMS errors between the observed and scaled wavenumbers are found to be 12.41 and 13.19 for IR and Raman wavenumbers. The small differences between experimental and calculated vibrational modes are observed. It must be due to the fact that hydrogen bond vibrations present in the crystal lead to strong perturbation of the infrared wavenumbers and intensities of many other modes. Also, we state that experimental results belong to solid phase and theoretical calculations belong to gaseous phase.

\section{SERS spectrum}

The relative intensities from SERS spectra are expected to differ significantly from normal Raman spectrum 
owing to specific surface selection rules. ${ }^{47}$ The surface selection rule suggest that for a molecule adsorbed flat on the silver surface, its out-of-plane bending modes will be more enhanced when compared with its in-plane bending modes and vice-versa when it is adsorbed perpendicular to the surface. ${ }^{47,48}$ It is further seen that vibrations involving atoms that are close to the silver surface will be enhanced. When the wavenumber difference between Raman bands in the normal and SERS spectra is not more than $5 \mathrm{~cm}^{-1}$, then the molecular plane will be perpendicular to the silver surface. ${ }^{49}$ In the case of the SERS spectrum of methyl(2-methyl-4,6-dinitro phenylsulfanyl)ethanoate ${ }^{14}$ the $\mathrm{CH}$ stretching mode of the methyl group in the methoxy carbonyl group appears at $2936 \mathrm{~cm}^{-1}$ shifted from $2962 \mathrm{~cm}^{-1}$ in the normal Raman spectrum. In the present study the methyl stretching vibration is observed at $2933 \mathrm{~cm}^{-1}$ in the SERS spectrum as a broad band shifted from $2958 \mathrm{~cm}^{-1}$ from the normal Raman spectrum. It should be related to the closeness of the methyl group to the silver surface. This is justifiable because the modes in groups directly interacting with the metal surface will be prominent in the SERS spectrum and undergo a wavenumber shift. ${ }^{50}$ Further, the methyl bands at $1465,1448,1427 \mathrm{~cm}^{-1}$ are also observed in the SERS spectrum thereby supporting the above argument. In our previous studies ${ }^{14}$ the symmetric stretching mode of $\mathrm{NO}_{2}$ is reported at $1346 \mathrm{~cm}^{-1}$ in the normal Raman spectrum and at $1319 \mathrm{~cm}^{-1}$ in the SERS spectrum. For 2-amino,5-nitropyrimidine ${ }^{51}$ the symmetric $\mathrm{NO}_{2}$ stretching mode corresponds to the most intense band, which appears broad and significantly downshifted from $1344 \mathrm{~cm}^{-1}$ (Raman) to $1326 \mathrm{~cm}^{-1}$ (SERS), suggesting a binding to silver surface through the lone pairs of oxygen atom. Carrasco et al. ${ }^{52}$ observed $v_{\text {as }} \mathrm{NO}_{2}$ band in the SERS spectrum at $c a .1500 \mathrm{~cm}^{-1}$ with medium intensity which demonstrates the importance of nitro group in regard to the interaction with the metal. Further, they observed the enhancement of $\mathrm{vPh}$ modes revealing that the molecule is oriented perpendicular to the metal surface where as the changes that occur in the nitro group indicates that the interaction occurs through $\mathrm{O}$ atoms of the nitro moiety. The interaction induces a $\pi$ electronic redistribution primarily around both the nitro group and the aromatic portion in the vicinity of substituent site. Also Gao and Weaver ${ }^{53}$ observed broadening and downshift of the corresponding band of nitrobenzene, adsorbed on gold via nitro group. For the title compound, the symmetric stretching mode of nitro group seen at $1345 \mathrm{~cm}^{-1}$ in the normal Raman spectrum appears at $1332 \mathrm{~cm}^{-1}$ in the SERS spectrum. A charge transfer from the oxygen atoms of the nitro group to the metal is evidenced by the marked downshift of the symmetric stretching mode of the nitro group as detected by SERS. ${ }^{51-53}$ Interaction through the nitro group was also supported by the presence of modes at 1635, 1567, 804, $741 \mathrm{~cm}^{-1}$ in the SERS spectrum. According to surface selection rules, vibrations involving atoms that are close to the silver surface will be enhanced. ${ }^{47,48}$

It has been well established that the presence or absence of the benzene ring $\mathrm{CH}$ stretching vibration is a reliable probe for the perpendicular or parallel orientation, respectively, of the benzene ring with respect to the metal surface. ${ }^{54,55}$ In the SERS spectrum of the title compound the aromatic $\mathrm{CH}$ stretching vibration is observed as a weak broad band at $3139 \mathrm{~cm}^{-1}$ which is absent in the normal Raman spectrum, which suggests that the phenyl ring may be in a position close to the perpendicular to the silver surface ${ }^{49,54,55}$ possibly a tilted position since it is a weak band. It has also been documented in literature ${ }^{56}$ when a benzene ring moiety interacts directly with a metal surface, the ring breathing mode has to be red shifted by ca. $10 \mathrm{~cm}^{-1}$ along with substantial band broadening in the SERS spectrum. Neither a substantial red shift nor significant band broadening was identified in the SERS spectrum of the title compound implying that the possibility of a direct ring $\pi$-orbital to metal interaction should be low, in accordance to a tilted position of the ring. Also, the in-plane $\mathrm{CH}$ vibrations of the phenyl ring are present in the SERS spectrum at $1188,1171 \mathrm{~cm}^{-1}$ as very weak bands and at $1041 \mathrm{~cm}^{-1}$ as a medium band. The out-of-plane CH mode is also present at $938 \mathrm{~cm}^{-1}$ in the SERS spectrum. This suggests that the benzene ring is oriented in a tilted position. The $\mathrm{vPh}$ vibrational modes corresponding to the bands at $1635,1567,1448,1383 \mathrm{~cm}^{-1}$ are weak in intensity in the SERS spectrum. Correspondingly, in the normal Raman spectrum, only a single strong band is observed at $1600 \mathrm{~cm}^{-1}$. This indicates an interaction between the phenyl ring and the metal surface. The presence of a sensitive substituent in-plane and out-of-plane modes, at $593,554,397,354 \mathrm{~cm}^{-1}$ supports the tilted orientation of the molecule on the metal surface.

The $\mathrm{C}=\mathrm{O}$ stretching band is absent in the SERS spectrum while the band of $\mathrm{VC}(=\mathrm{O}) \mathrm{O}$ is present at $1254 \mathrm{~cm}^{-1}$ in the SERS spectrum. The presence of methyl group modes in the SERS spectrum indicates the closeness of the methyl group with the metal surface and a possible interaction of the silver surface with the carbonyl group. This is supported by the strong band at $241 \mathrm{~cm}^{-1}$ which may be due to $\mathrm{Ag}-\mathrm{O}$ stretching vibration. ${ }^{50,57,58}$ This band may be due to $\mathrm{Ag}-\mathrm{O} / \mathrm{Ag}-\mathrm{S}$ stretching vibration. But in the SERS spectrum, nitro and carbonyl group vibrations are affected and the absence of the sulfur group vibration indicates that the $241 \mathrm{~cm}^{-1}$ band is due to Ag-O stretch. We have reported similar strong band at $c a .240 \mathrm{~cm}^{-1}$ for the Ag-O stretching vibration in earlier studies. ${ }^{14,57}$ 


\section{Conclusions}

SERS spectroscopy is a good technique for studying adsorption of molecules on metal surface. From the SERS spectrum we have deduced that the title compound has a tilted orientation on the silver surface. Significant metal-molecule interaction has been substantiated by the appearance of intense Ag-O mode in the SERS spectrum and this is indicative of the nearness of nitro and carbonyl group to the silver surface. The presence of methyl modes in the SERS spectrum shows the nearness of the methyl group to the metal surface and it affects the orientation and metal molecule interaction. The calculated vibrational wavenumbers obtained on theoretical method are in good agreement with the experimental values obtained for the investigated molecule.

\section{Supplementary Information}

Supplementary data, optimized geometry of the molecule are available free of charge at http://jbcs.sbq. org.br, as PDF file.

\section{References}

1. Fleischmann, M.; Hendra, P. J.; McQuillan, A. J.; Chem. Phys. Lett. 1974, 26, 163.

2. JeanMaire, D. L.; Van Duyne, R. R.; J. Electroanal. Chem. 1977, $84,1$.

3. Dudova, K.; Castek, F.; Machacek, V.; Simunek, P.; Molecules 2002, 7, 7 .

4. Erben, M. F.; Della Vedova, C. O.; Romano, R. M.; Boese, R.; Oberhammer, H.; Willner, H.; Sala, O.; Inorg. Chem. 2002, 41, 1064.

5. Vallejos, S. T.; Erben, M. F.; Willner, H.; Boese, R.; Della Vedova, C. O.; J. Org. Chem. 2007, 72, 9074.

6. Lajumen, L. H. J.; Kokkonen, P.; Nissi, A.; Ruotsalainen, H.; Thermochim. Acta 1984, 72, 219.

7. Anjaneyulu, Y.; Rao, N. V. S.; Rao, P. R.; Murthy, L. N.; Pisipati, V. G. K. M.; Indian J. Pure Appl. Phys. 1986, 24, 256.

8. Ranford, J. D.; Sadler, P. J.; Tocher, D. A.; J. Chem. Soc., Dalton Trans. 1993, 22, 3393.

9. Valigura, D.; Melnik, M.; Komen, M.; Martiska, L.; Korabik, M.; Mrozinsky, J.; Glowiak, T.; Polyhedron 2004, 23, 2447.

10. Valigura, D.; Melnik, M.; Komen, M.; Martiska, L.; Korabik, M.; Glowiak, T.; Inorg. Chem. Commun. 2004, 7, 548.

11. Smith, G.; Wermuth, U. D.; White, J. M.; Acta Crystallogr. 2001, E57, 1036.

12. Smith, G.; Lyncy, D. E.; Byriel, K. A.; Kennard, C. H. L.; Aust. J. Chem. 1995, 48, 1133.
13. Kumar, V. S. S.; Kuduva, S. S.; Desiraju, G.R.; J. Chem. Soc., Perkin Trans. 1999, 2, 1069.

14. Panicker, C. Y.; Varghese, H. T.; Philip, D.; Nogueira, H. I. S.; Castkova. K.; Spectrochim. Acta Part A 2007, 67, 1313.

15. Frisch, M. J.; Trucks, G. W.; Schlegel, H. B.; Scuseria, G. E.; Robb, M. A.; Cheeseman, J. R.; Montgomery, Jr. J. A.; Vreven, T.; Kudin, K. N.; Burant, J. C.; Millam, J. M.; Iyengar, S. S.; Tomasi, J.; Barone, V.; Mennucci, B.; Cossi, M.; Scalmani, G.; Rega, N.; Petersson, G. A.; Nakatsuji, H.; Hada, M.; Ehara, M.; Toyota, K.; Fukuda, R.; Hasegawa, J.; Ishida, M.; Nakajima, T.; Honda, Y.; Kitao, O.; Nakai, H.; Klene, M.; Li, X.; Knox, J. E.; Hratchian, H. P.; Cross, J. B.; Adamo, C.; Jaramillo, J.; Gomperts, R.; Stratmann, R. E.; Yazyev, O.; Austin, A. J.; Cammi, R.; Pomelli, C.; Ochterski, J. W.; Ayala, P. Y.; Morokuma, K.; Voth, G. A.; Salvador, P.; Dannenberg, J. J.; Zakrzewski, V. G.; Dapprich, S.; Daniels, A. D.; Strain, M. C.; Farkas, O.; Malick, D. K.; Rabuck, A. D.; Raghavachari, K.; Foresman, J. B.; Ortiz, J. V.; Cui, Q.; Baboul, A. G.; Clifford, S.; Cioslowski, J.; Stefanov, B. B.; Liu, G.; Liashenko, A.; Piskorz, P.; Komaromi, I.; Martin, R. L.; Fox, D. J.; Keith, T.; Al-Laham, M. A.; Peng, C. Y.; Nanayakkara, A.; Challacombe, M.; Gill, P. M. W.; Johnson, B.; Chen, W.; Wong, M. W.; Gonzalez, C.; Pople, J. A.; Gaussian 03, Revision C.02 Gaussian, Inc.: Wallingford, CT, 2004.

16. Lee, P. C.; Meisel, D. J.; J. Phys. Chem. 1982, 86, 3391.

17. Nogueira, H. I. S.; Spectrochim. Acta Part A 1998, 54, 1461.

18. Foresman, J. B.; Frisch, E.; Exploring Chemistry with Electronic Structure Methods: A Guide to using Gaussian; Gaussian Inc: Pittsburg, PA, 1996.

19. Scott, A. P.; Radom, L.; J. Phys. Chem. A 1996, 100, 16502.

20. Rauhut, G.; Pulay, P.; J. Phys. Chem. 1995, 99, 3093.

21. Flukiger, P.; Luthi, H. P.; Portmann S, Weber, J.; MOLEKEL 4.3; Swiss Centre for Scientific Computing, Manno, Switzerland, 2000-2002.

22. Portmann, S.; Luthi, H. P.; Chimia 2000, 54, 766.

23. Roeges, N. P. G.; A Guide to the Complete Interpretation of Infrared Spectra of Organic Structures, Wiley: New York, 1994.

24. Silverstein, R. M.; Bassler, G. C.; Morril, T. C.; Spectrometic Identification of Organic Compounds, $5^{\text {th }}$ ed., John Wiley and Sons Inc.: Singapore, 1991.

25. Philip, D.; John, A.; Panicker, C. Y.; Varghese, H. T.; Spectrochim. Acta Part A 2001, 57, 1561.

26. Panicker, C. Y.; Varghese, H. T.; John, A.; Philip, D.; Istvan, K.; Keresztury, G.; Spectrochim. Acta Part A 2002, 58, 281.

27. Varghese, H. T.; Panicker, C. Y.; Philip, D.; Chowdhury, J.; Ghosh, M.; J. Raman Spectrosc. 2007, 38, 323.

28. Seth Paul, W. A.; Van Duyse, A.; Spectrochim. Acta Part A 1972, 28, 211.

29. Nyquist, R. A.; Appl. Spectrosc. 1972, 26, 81.

30. Sajan, D.; Binoy, J.; Joe, I. H.; Jayakumar, V. S.; Zaleski, J.; J. Raman Spectrosc. 2005, 36, 221. 
31. Saunders, J. E.; Lucier, J. J.; Bentley, F. F.; Appl. Spectrosc. 1968, 22, 697.

32. Prejessy, A.; Rasala, D.; Tomasik, P.; Gawinecki, R.; Collect. Czech. Chem. Commun. 1985, 50, 2443.

33. Brown Jr, J. F.; J. Am. Chem. Soc. 1955, 77, 6341.

34. Exner, O.; Kovac, S.; Solcaniovas, E.; Collect. Czech. Chem. Commun. 1972, 37, 2156.

35. Ranga Rao, D. S.; Thyagarajan, G.; Indian J. Pure Appl. Phys. 1978, 16, 941 .

36. Varsanyi, G.; Molner-Paal, E.; Kosa, K.; Keresztury, G.; Acta Chim. Acad. Sci. Hung. 1979, 106, 481.

37. Suryanaranaya ,V.; Kumar, A. P.; Rao, G. R.; Pandey, G. C.; Spectrochim Acta Part A 1992, 48, 1481.

38. Colthup, N. B.; Daly, L. H.; Wiberly, S. E.; Introduction to Infrared and Raman Spectroscopy, $2^{\text {nd }}$ ed., Academic Press: New York, 1985.

39. McMurry, H. L.; Thornton, V.; Anal. Chem. 1952, 24, 318.

40. Varsanyi. G.; Assignments of Vibrational Spectra of Seven Hundred Benzene Derivatives, Wiley: New York, 1974.

41. Socrates. G.; Infrared and Raman characteristic Group frequencies, Wiley: Middlesex, UK, 2001.

42. Ng, S. W.; Naumov, P.; Drew, M. G. B.; Wojciechowski, G.; Brzezinski, B.; J. Mol. Struct. 2001, 595, 29.

43. Bujak, M.; Zaleski, J.; Preszhdo, V.; Uspienskij, B.; Acta Crystallogr. 2002, 58C, 76.

44. Rumi, M.; Zerbi, G.; J. Mol. Struct. 1999, 509, 11.

45. Kurtz, S. K.; Perry, T. T.; J. Appl. Phys. 1968, 39, 3798.
46. Krishnakumar, V.; Dheivamalar, S.; Xavier, R. J.; Balachandran, V.; Spectrochim. Acta Part A 2006, 65, 147.

47. Creighton, J. A.; Spectroscopy of Surfaces - Advances in Spectroscopy, Wiley: New York, 1988, vol. 16, p. 37 (Chapter 2).

48. Gao, X.; Davies, J. P.; Weaver, M. J.; J. Phys. Chem. A 1990, 94, 6858.

49. Levi, G.; Patigny, J.; Massault, J. A.; Aubard J.; $13^{\text {th }}$ International Conference on Raman Spectroscopy, Wurzburg, 1992, p. 652.

50. Kai, S.; Chaozhi, W.; Guangzhi, X.; Spectrochim. Acta Part A 1989, 45, 1029.

51. Muniz-Miranda, M.; Vib. Spectrosc. 2002, 29, 229.

52. Carrasco, E. A.; Campos-Vallett, M.; Leyton, P.; Diaz, G.; Clavijo, R. E.; Garcia-Ramos, J. V.; Inostroza, N.; Domingo, C.; Sanchez-Cortes, S.; Koch, R.; J. Phys. Chem. A 2003, 107, 9611.

53. Gao, P.; Weaver, M. J.; J. Phys. Chem. 1985, 89, 5040.

54. Suh, J. S.; Moskovits, M.; J. Am. Chem. Soc. 1986, 108, 4711.

55. Creighton, J. A.; Surf. Sci. 1983, 124, 209.

56. Gao, P.; Weaver, M. J.; J. Phys. Chem. A 1989, 93, 6205.

57. Panicker, C. Y.; Varghese, H. T.; Philip, D.; Nogueira, H. I. S.; Spectrochim. Acta 2006, 64A, 744.

58. Greaves, S. J.; Griffith, W. P.; J. Raman Spectrosc. 1988, 19, 503.

Received: August 12, 2008 Web Release Date: March 6, 2009 


\section{IR, Raman and SERS Spectra of 2-(Methoxycarbonylmethylsulfanyl)-3,5-dinitrobenzene Carboxylic Acid}

\section{Asha Raj, ${ }^{a}$ K.Raju, ${ }^{b}$ Hema Tresa Varghese, ${ }^{c}$ Carlos M. Granadeiro, ${ }^{d}$ Helena I. S. Nogueira ${ }^{d}$ and C.Yohannan Panicker*,e}

${ }^{a}$ Department of Physics, Government Polytechnic College, Attingal, Kerala, India

${ }^{b}$ Department of Physics, University College, Trivandrum, Kerala, India

${ }^{c}$ Department of Physics, Fatima Mata National College, Kollam, Kerala, India

${ }^{d}$ Department of Chemistry, CICECO, University of Aveiro, 3810-193 Aveiro, Portugal

${ }^{e}$ Department of Physics, TKM College of Arts and Science, Kollam, Kerala, India

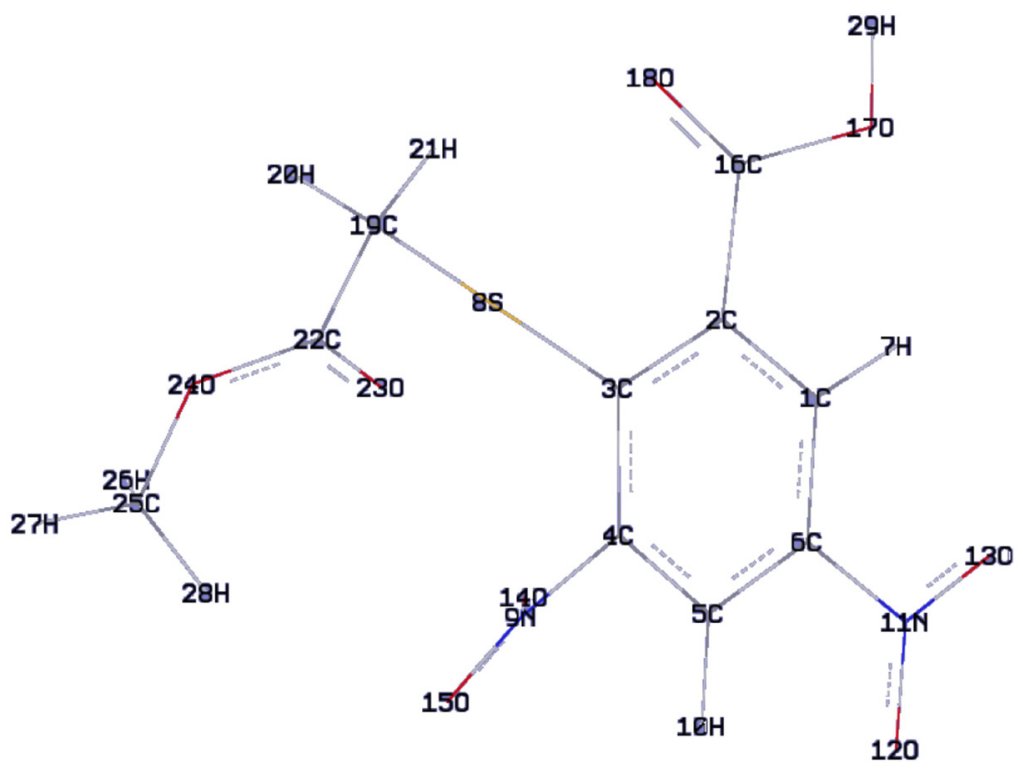

Figure S1. Optimized geometry of the molecule. 
Table S1. Optimized geometrical parameters of 2-(methoxycarbonylmethylsulfanyl)-3,5-nitrobenzenecarboxylicacid, atom labeling is according to Figure 4.

\begin{tabular}{|c|c|c|c|c|c|}
\hline \multicolumn{2}{|c|}{ Bond length $/(\AA)$} & \multicolumn{2}{|c|}{ Bond angles $\left({ }^{\circ}\right)$} & \multicolumn{2}{|c|}{ Dihedral angles $\left({ }^{\circ}\right)$} \\
\hline $\mathrm{C}_{1}-\mathrm{C}_{2}$ & 1.4006 & $\mathrm{~A}(2,1,6)$ & 120.1 & $\mathrm{D}(6,1,2,3)$ & 0.7 \\
\hline $\mathrm{C}_{1}-\mathrm{C}_{6}^{2}$ & 1.3865 & $\mathrm{~A}(2,1,7)$ & 120.5 & $\mathrm{D}(6,1,2,16)$ & 179.6 \\
\hline $\mathrm{C}_{1}-\mathrm{H}_{7}$ & 1.0812 & $\mathrm{~A}(6,1,7)$ & 119.4 & $\mathrm{D}(7,1,2,3)$ & -179.4 \\
\hline $\mathrm{C}_{2}-\mathrm{C}_{3}$ & 1.4199 & $\mathrm{~A}(1,2,3)$ & 120.2 & $\mathrm{D}(7,1,2,16)$ & -0.5 \\
\hline $\mathrm{C}_{2}^{2}-\mathrm{C}_{16}^{3}$ & 1.4990 & $\mathrm{~A}(1,2,16)$ & 116.9 & $\mathrm{D}(2,1,6,5)$ & -1.7 \\
\hline $\mathrm{C}_{3}{ }_{3}-\mathrm{C}_{4}$ & 1.4077 & $\mathrm{~A}(3,2,16)$ & 122.8 & $\mathrm{D}(2,1,6,11)$ & 178.7 \\
\hline $\mathrm{C}_{3}-\mathrm{S}_{8}$ & 1.7949 & $\mathrm{~A}(2,3,4)$ & 116.6 & $\mathrm{D}(7,1,6,5)$ & 178.5 \\
\hline $\mathrm{C}_{4}^{3}-\mathrm{C}_{5}^{8}$ & 1.3870 & $\mathrm{~A}(2,3,8)$ & 125.0 & $\mathrm{D}(7,1,6,11)$ & -1.2 \\
\hline $\mathrm{C}_{4}^{4}-\mathrm{N}_{9}^{5}$ & 1.4774 & $\mathrm{~A}(4,3,8)$ & 118.4 & $\mathrm{D}(1,2,3,4)$ & 2.2 \\
\hline $\mathrm{C}_{5}^{4}-\mathrm{C}_{6}$ & 1.3868 & $\mathrm{~A}(3,4,5)$ & 123.8 & $\mathrm{D}(1,2,3,8)$ & -178.7 \\
\hline $\mathrm{C}_{5}^{5}-\mathrm{H}_{10}$ & 1.0825 & $\mathrm{~A}(3,4,9)$ & 121.1 & $\mathrm{D}(16,2,3,4)$ & -176.6 \\
\hline $\mathrm{C}_{6}-\mathrm{N}_{11}$ & 1.4741 & $\mathrm{~A}(5,4,9)$ & 115.2 & $\mathrm{D}(16,2,3,8)$ & 2.5 \\
\hline $\mathrm{S}_{8}-\mathrm{C}_{19}$ & 1.8493 & $\mathrm{~A}(4,5,6)$ & 117.5 & $\mathrm{D}(1,2,16,17)$ & -22.4 \\
\hline $\mathrm{N}_{9}-\mathrm{O}_{14}$ & 1.2244 & $\mathrm{~A}(4,5,10)$ & 121.4 & $\mathrm{D}(1,2,16,18)$ & 157.7 \\
\hline $\mathrm{N}_{9}-\mathrm{O}_{15}^{14}$ & 1.2292 & $\mathrm{~A}(6,5,10)$ & 121.1 & $\mathrm{D}(3,2,16,17)$ & 156.4 \\
\hline $\mathrm{N}_{11}-\mathrm{O}_{12}$ & 1.2287 & $\mathrm{~A}(1,6,5)$ & 121.6 & $\mathrm{D}(3,2,16,18)$ & -23.5 \\
\hline $\mathrm{N}_{11}-\mathrm{O}_{13}$ & 1.2284 & $\mathrm{~A}(1,6,11)$ & 119.3 & $\mathrm{D}(2,3,4,5)$ & -4.6 \\
\hline $\mathrm{C}_{16}-\mathrm{O}_{17}$ & 1.3546 & $\mathrm{~A}(5,6,11)$ & 119.0 & $\mathrm{D}(2,3,4,9)$ & 176.0 \\
\hline $\mathrm{C}_{16}^{16}-\mathrm{O}_{18}^{1 /}$ & 1.2119 & $\mathrm{~A}(3,8,19)$ & 101.2 & $\mathrm{D}(8,3,4,5)$ & 176.3 \\
\hline $\mathrm{O}_{17}^{16}-\mathrm{H}_{29}^{18}$ & 0.9756 & $\mathrm{~A}(4,9,14)$ & 117.1 & $\mathrm{D}(8,3,4,9)$ & -3.1 \\
\hline $\mathrm{C}_{19}-\mathrm{H}_{20}^{29}$ & 1.0925 & $\mathrm{~A}(4,9,15)$ & 116.7 & $\mathrm{D}(2,3,8,19)$ & 70.8 \\
\hline $\mathrm{C}_{19}^{19}-\mathrm{H}_{21}^{20}$ & 1.0883 & $\mathrm{~A}(14,9,15)$ & 126.1 & $\mathrm{D}(4,3,8,19)$ & -110.1 \\
\hline $\mathrm{C}_{19}-\mathrm{C}_{22}^{21}$ & 1.5131 & $\mathrm{~A}(6,11,12)$ & 117.2 & $\mathrm{D}(3,4,5,6)$ & 3.7 \\
\hline $\mathrm{C}_{22}-\mathrm{O}_{23}$ & 1.2139 & $\mathrm{~A}(6,11,13)$ & 117.4 & $\mathrm{D}(3,4,5,10)$ & -176.2 \\
\hline $\mathrm{C}_{22}^{22}-\mathrm{O}_{24}^{23}$ & 1.3429 & $\mathrm{~A}(12,11,13)$ & 125.4 & $\mathrm{D}(9,4,5,6)$ & -176.9 \\
\hline $\mathrm{O}_{24}^{22}-\mathrm{C}_{25}^{24}$ & 1.4418 & $\mathrm{~A}(2,16,17)$ & 111.3 & $\mathrm{D}(9,4,5,10)$ & 3.2 \\
\hline $\mathrm{C}_{25}^{24}-\mathrm{H}_{26}^{25}$ & 1.0926 & $\mathrm{~A}(2,16,18)$ & 126.8 & $\mathrm{D}(3,4,9,14)$ & -57.6 \\
\hline $\mathrm{C}_{25}^{25}-\mathrm{H}_{27}^{26}$ & 1.0898 & $\mathrm{~A}(17,16,18)$ & 121.9 & $\mathrm{D}(3,4,9,15)$ & 124.7 \\
\hline \multirow{26}{*}{$\mathrm{C}_{25}-\mathrm{H}_{28}$} & 1.0930 & $\mathrm{~A}(16,17,29)$ & 106.0 & $\mathrm{D}(5,4,9,14)$ & 122.9 \\
\hline & & $\mathrm{A}(8,19,20)$ & 103.9 & $\mathrm{D}(5,4,9,15)$ & -54.8 \\
\hline & & $\mathrm{A}(8,19,21)$ & 109.4 & $\mathrm{D}(4,5,6,1)$ & -0.5 \\
\hline & & $\mathrm{A}(8,19,22)$ & 109.6 & $\mathrm{D}(4,5,6,11)$ & 179.2 \\
\hline & & $\mathrm{A}(20,19,21)$ & 110.8 & $\mathrm{D}(10,5,6,1)$ & 179.5 \\
\hline & & $\mathrm{A}(20,19,22)$ & 111.7 & $\mathrm{D}(10,5,6,11)$ & -0.8 \\
\hline & & $\mathrm{A}(21,19,22)$ & 111.2 & $\mathrm{D}(1,6,11,12)$ & 178.3 \\
\hline & & $\mathrm{A}(19,22,23)$ & 123.6 & $\mathrm{D}(1,6,11,13)$ & -1.6 \\
\hline & & $\mathrm{A}(19,22,24)$ & 111.8 & $\mathrm{D}(5,6,11,12)$ & -1.3 \\
\hline & & $\mathrm{A}(23,22,24)$ & 124.5 & $\mathrm{D}(5,6,11,13)$ & 178.8 \\
\hline & & $\mathrm{A}(22,24,25)$ & 115.3 & $\mathrm{D}(3,8,19,20)$ & 178.0 \\
\hline & & $\mathrm{A}(24,25,26)$ & 110.5 & $\mathrm{D}(3,8,19,21)$ & -63.6 \\
\hline & & $\mathrm{A}(24,25,27)$ & 105.4 & $\mathrm{D}(3,8,19,22)$ & 58.6 \\
\hline & & $\mathrm{A}(24,25,28)$ & 109.8 & $\mathrm{D}(2,16,17,29)$ & 178.4 \\
\hline & & $\mathrm{A}(26,25,27)$ & 110.8 & $\mathrm{D}(18,16,17,29)$ & -1.7 \\
\hline & & $\mathrm{A}(26,25,28)$ & 109.5 & $\mathrm{D}(8,19,22,23)$ & -83.6 \\
\hline & & $\mathrm{A}(27,25,28)$ & 110.7 & $\mathrm{D}(8,19,22,24)$ & 93.7 \\
\hline & & & & $\mathrm{D}(20,19,22,23)$ & 161.8 \\
\hline & & & & $\mathrm{D}(20,19,22,24)$ & -20.9 \\
\hline & & & & $\mathrm{D}(21,19,22,23)$ & 37.5 \\
\hline & & & & $\mathrm{D}(21,19,22,24)$ & -145.2 \\
\hline & & & & $\mathrm{D}(19,22,24,25)$ & -173.7 \\
\hline & & & & $\mathrm{D}(23,22,24,25)$ & 3.5 \\
\hline & & & & $\mathrm{D}(22,24,25,26)$ & -58.9 \\
\hline & & & & $\mathrm{D}(22,24,25,27)$ & -178.7 \\
\hline & & & & $\mathrm{D}(22,24,25,28)$ & 62.0 \\
\hline
\end{tabular}

